\title{
A novel risk of air embolism with intravenous paracetamol
}

\author{
Ian Davies, James David Griffin \\ Department of Anaesthetics, South Devon Healthcare NHS Foundation Trust, Torquay, UK
}

Correspondence to Dr lan Davies, ian.davies2@nhs.net

\section{DESCRIPTION}

Air embolism following the administration of intravenous paracetamol is a risk because it is stored in a rigid container, and therefore requires an air inlet to allow infusion. ${ }^{1}$ At the end of the infusion, if the giving-set is not clamped, air may be entrained, particularly into a central vein. Venous air embolism of a volume of $5 \mathrm{ml} / \mathrm{kg}$ may cause cardiac arrest, but considerably smaller volumes $(2$ or $3 \mathrm{ml}$ ) have been associated with complications in coronary and cerebral circulations. ${ }^{2}$ We present a 'near-miss' in an orthopaedic theatre, with a patient undergoing an elective hip-replacement. Intravenous paracetamol was given intraoperatively via a peripheral vein, but the air inlet/needle was positioned too close to the aperture of the giving-set, creating a direct communication between the two. This allowed air to pass directly from the air inlet into the giving set without the infusion progressing. The fluid level in the rigid container did not decrease but air was still entrained into the giving set, which was only noticed when the giving set was almost full of air, although none had reached the patient. While the Summary of Product Characteristics for Perfalgan intra-venous paracetamol ${ }^{3}$ mentions the need for close monitoring of the infusion, this focuses on the end of an infusion. In the above scenario, the infusion may not seemingly progress at all, but large volumes of air may be entrained as soon as the giving set is unclamped. Careful assembly and close monitoring throughout the infusion is vital to avoid a potentially fatal complication (figure 1).

\section{Learning points}

- Rigid or semirigid containers present a risk of air embolism as an air inlet must be introduced to allow infusion.

- Agents commonly stored in such containers include paracetamol, metronidazole, ciprofloxacin, propofol, sodium bicarbonate, or phosphate solutions as well as certain preparations of colloids and crystalloids.

- A direct connection of air between the inlet and the giving set can bypass the infusion chamber and cause an air embolism before the infusion has even started.

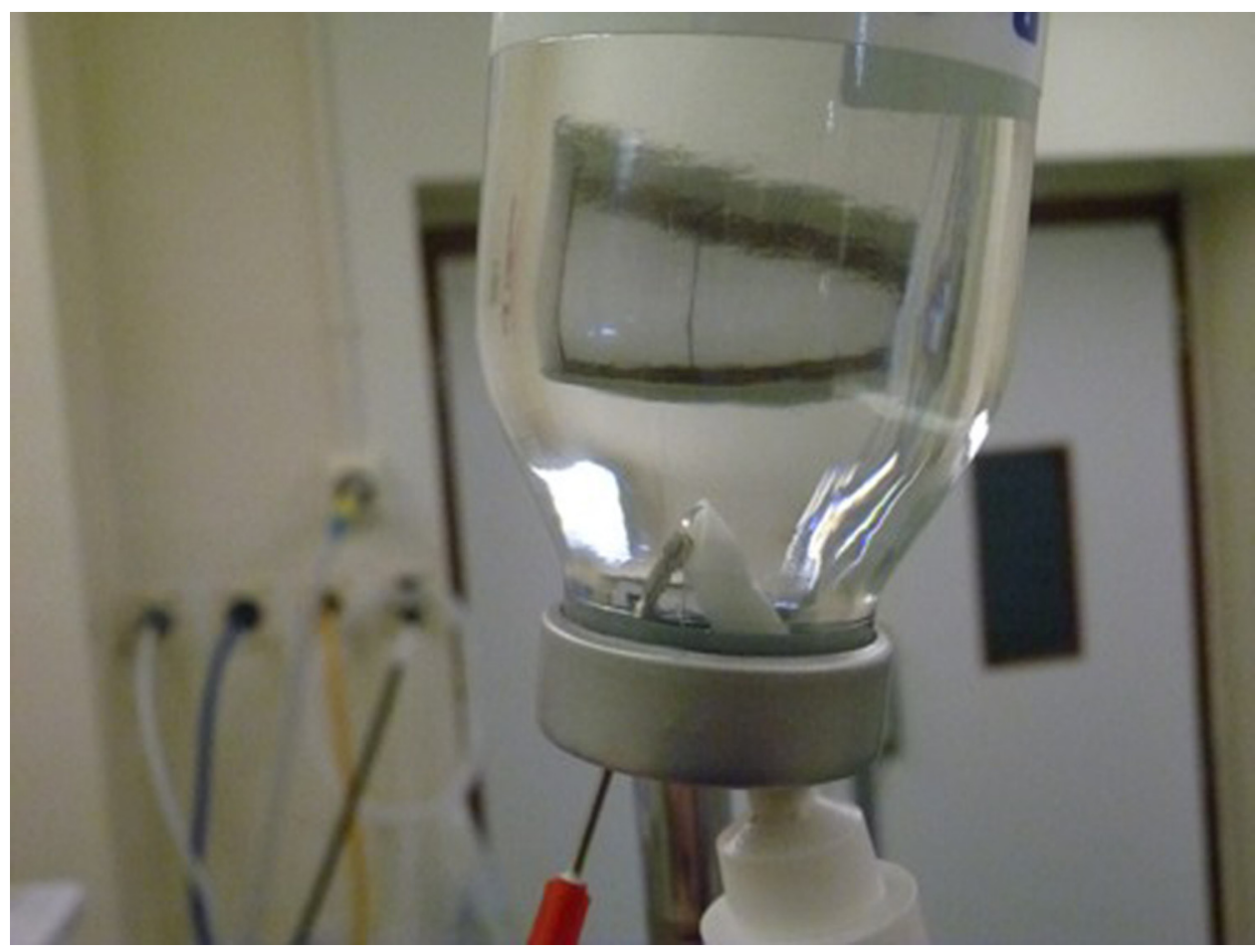

Figure 1 An air bubble is clearly visible passing directly from the air inlet needle to the giving set. 


\section{BMJ Case Reports}

\section{Competing interests None.}

Patient consent Not obtained.

\section{REFERENCES}

1. Pierson R, Coupe M. Reducing the risk of air embolism following administration of intravenous paracetamol. Anaesthesia 2008;63:104-5: discussion 105.
2. Ho AM. Is emergency thoracotomy always the most appropriate immediate intervention for systemic air embolism after lung trauma? Chest 1999;116:234-7.

3. Electronic Medicines Compendium: Perfalgan Summary of Product Characteristics [Online]. 2010 [cited 6th December 2011]. Available from: http://www.medicines.org.uk/EMC/medicine/14288/SPC/Perfalgan +10mg + $\mathrm{ml}++$ Solution + for + Infusion/ (accessed 6 December 2011)

This pdf has been created automatically from the final edited text and images.

Copyright 2012 BMJ Publishing Group. All rights reserved. For permission to reuse any of this content visit

http://group.bmi.com/group/rights-licensing/permissions.

BMJ Case Report Fellows may re-use this article for personal use and teaching without any further permission.

Please cite this article as follows (you will need to access the article online to obtain the date of publication).

Davies I, Griffin JD. A novel risk of air embolism with intravenous paracetamol. BMJ Case Reports 2012;10.1136/bcr.01.2012.5488, Published XXX

Become a Fellow of BMJ Case Reports today and you can:

- Submit as many cases as you like

- Enjoy fast sympathetic peer review and rapid publication of accepted articles

- Access all the published articles

- Re-use any of the published material for personal use and teaching without further permission

For information on Institutional Fellowships contact consortiasales@bmjgroup.com

Visit casereports.bmj.com for more articles like this and to become a Fellow

Keep up to date with all published cases by signing up for an alert (all we need is your email address) http://casereports.bmj.com/cgi/alerts/etoc 